\title{
Justification of Requirements for Crushed Rock for Open-pit Automobile Road Topping
}

\author{
Shabaev Sergey N. ${ }^{1, a}$, Boyko Dmitriy V., \\ ${ }^{1}$ T. F. Gorbachev Kuzbass State Technical University, \\ Kemerovo, Russian Federation \\ ae-mail: shabaev81@ @rambler.ru, be-mail: boiko_dmitrii87@mail.ru
}

\begin{abstract}
The rational size distribution of the granular materials is proved in this paper on the basis of the theoretical studies of their optimal structure based on the particle-particle packing probability theory, the laboratory studies in the dependencies of bulk density and static modulus of elasticity of the content of particles of various sizes as well as the calculation of the ultimate crushed rock shearing resistance. The suggestions on the recommended brands according to their frost hardiness, shatter, abrasion and water resistance of the crushed rock used for the open-pit automobile road toppings and bases, based on the analysis of the impact of climatic conditions and loads from the impact of technological vehicles on operational performance of pavement layer, are also given.
\end{abstract}

Keywords - Open-pit; open-cut mine; rock; road; topping; property; elasticity; shear; composition; resistance.

\section{INTRODUCTION}

Topping is one of the most important elements of the pavement layer of open-pit automobile roads, on the condition of which the average speed of open-pit automobile traffic and, accordingly, its performance depend to a large extent [1]. Given that transport costs account for between 40 to $70 \%$ of the total costs [2], improving the quality of topping is one of the main ways to reduce the cost of production of minerals by open-pit mining method [3].

\section{SUBJECT OF RESEARCH}

The review of the literature [4-8] and the experience of opencast coal mines of Kuzbass have shown that the construction of asphalt concrete and cement concrete pavements is not economically justified, when we are talking about the roads located in a dynamically developing open-pit space where the temporary roads are up to $80 \%$ of their entire length. The experience has shown that the crushed rocks are the most suitable for the pavement construction of both permanent and temporary technological roads.

Despite the fact that, according to [9], which is referred to the normative document [10], only the dense rubble-gravelsand mixtures (crushed rocks of predetermined particle size distribution) can be used as the crushed rock for road paving, in practice the design organizations continue to apply both the one-stone grading gravel and the choke crushed stone, as the topping material. This fact can be explained by the reference to the standard operating procedures [11], but this leads to the rapid destruction of such pavement layers and, consequently, to low efficiency of operation of open-pit motor vehicles, which requires deeper study of the issue on the effective use of crushed rock for open-pit road topping. One of the main unsolved issues of their effective use is the desired particle size distribution.

The analysis of the results of research carried out earlier showed that the crushed rock of optimum particle size distribution should consist of different size particles, taken in the certain proportion, providing the increased internal friction and the adhesion between particles, the high bulk density and the low grain grinding intensity [12-15]. These conditions can be achieved with the maximum possible amount of coarse particles and the minimum necessary amount to produce the high bulk density and to ensure the cohesiveness of coarse particles in the content of fine and dust particles.

\section{RESULTS AND DISCUSSIONS}

These findings based on the basic theoretical propositions of A.V. Biryukova, B.S. Radovsky and I.I. Kandaurova [1618] are the basis of the theoretical model of the optimum packaging of different size particles. In this theoretical model, the following assumptions and suggestions have been introduced:

1. All the crushed rock is composed of $N$-components; the certain fraction, characterized by the average diameter being taken as a component. It is inconvenient to use the absolute values of the average particle diameter, so the mean particle diameters of certain fractions were replaced in the theoretical model with the relative dimensions such as $D \max , D \max / 2$, $D$ max/4 and so on.

2. The particles of the largest component are distributed uniformly throughout the volume, which allows considering not the totality of the particles (macroobject), but only one of them (binary object).

3. All particles have a spherical shape. If we take the particles form as a cube, theoretically the minimum voidage of the crushed rock layer will tend to the porosity of the rock itself since the individual particles can tightly contact with each other on all the sides. Tetrahedron-like shape is difficult to consider using a random packing of particles since the grains may occupy one position, but always have the different orientations in space. But the shape of the particles in the form 
of a ball fulfils both the conditions: between the particles there is always the space (void) that cannot be filled completely; regardless of the location of an individual particle, its orientation in space does not affect the packing.

The essence of the theoretical model is that the largest component and the space adjacent to it, we consider as an elementary area (the bounded discrete structure), a set of which constitute the macrostructure. The space consisting of empty cells having a size sufficient for the discretization of the finest of components that make up the crushed rock is formed within the discrete structure. We insert the largest component into central part of the region and further by repeated random selection of the component gravity centre locations having the average particle diameter $D \max / 2$ we try to insert the component till the largest possible filling of discrete structure. In the course of the discrete structure filling with the smaller components we put a condition that if at least one of the cells, which must be filled with the smaller components, falls on any cell already filled with the larger component, we randomly choose a new gravity centre locations of this component and the process repeats. Thus, first we insert the component having an average particle diameter $D \max$ into the discrete structure, and then try to fill all the space remaining free with the component having an average particle size $D \max / 2$, further we conduct the similar operations with the component having an average particle diameter $D \max / 4$, and so further.

To test the adequacy of the theoretical model, we conducted the laboratory studies of the dependencies of the bulk density and the static modulus of elasticity of crushed rocks of different particle size distribution. In addition, the ultimate crushed rock shearing resistance has been defined by means of calculation. The laboratory tests were carried out in the following sequence:

1. We moved the crushed rock sample from the exsiccator to a metal or plastic plate and mixed thoroughly.

2. We loaded the crushed rock in the complete mould: the mould was filled with the crushed rock in three equal layers, each layer being rodded by the $12 \mathrm{~mm}$ diameter steel rod with the rounded end; the number of rod pushes was taken equal to 25; rodding was performed uniformly in a spiral shape from the edges to the middle.

3. The mould was placed on the press plate, the hard punch was adjusted to the surface of the crushed rock layer, and dial gauges were also fixed.

4. The readings were read within the accuracy of 0.001 $\mathrm{mm}$.

5. We vented the hydraulic pressing of $2.5 \mathrm{MPa}$ passed, which was maintained for 2 minutes to compact the crushed rock layer.

6. We removed the load and again took the readings; if the difference in the readings of dial gauges before and after loading exceeded $0.002 \mathrm{~mm}$, it was believed that the crushed rock was contracted, and the repeated loading was made.

7. To measure the elastic deformation the pressure 0.5 MPa was applied to the layer under the test and maintained for 2 minutes; after a specified time the three dial readings were taken, the load was removed, and re-readings were taken with an accuracy of $0.001 \mathrm{~mm}$; the magnitude of the elastic deformation of the crushed rock $l_{y}, \mathrm{~mm}$, was determined by the formula:

$$
l_{y}=\frac{\sum_{i=1}^{3}\left(L_{i}-l_{i}\right)}{3}
$$

In the type: $L_{i}-\mathrm{i}$-dial reading after the load application, $\mathrm{mm}$; $l_{i}$ _ dial reading under the load, $\mathrm{mm}$.

8. As a result of the four measurements in different quarters of the mould, determined by the calipers the average height from the upper edge of the mould to the crushed rock layer with an accuracy of up to $0.1 \mathrm{~mm}$;

9. On balance with an accuracy of $1 \mathrm{~g}$ we weighed the mould with the crushed rock and calculated its bulk density $\left(\rho_{w}\right)$, taking into account the presence of water with an accuracy of up to $0.01 \mathrm{~g} / \mathrm{cm}^{3}$ :

$$
\rho_{w}=\frac{m_{1}-m_{2}}{V_{m}}
$$

In the type: $m_{1}$ - the mass of the mould with the crushed rock, $\mathrm{g} ; m_{2}$ - the mass of the mould without the crushed rock, $\mathrm{g}$; $V_{m}$ - the actual volume of the crushed rock in the mould, $\mathrm{cm}^{3}$, calculated with an accuracy of up to $1 \mathrm{~cm}^{3}$ by the formula:

$$
V_{m}=\frac{\pi \cdot D^{2}}{4} \cdot(H-h)
$$

In the type: $\pi$ - the coefficient, equal to $3.14 ; D-$ the mould diameter, см; $H$ - the mould height, см; $h$ - the average height from the upper edge of the mould to the crushed rock layer, cм.

10. We calculated the bulk density of the crushed rock $\rho$, without accounting for the presence of water with an accuracy of up to $0.01 \mathrm{~g} / \mathrm{cm}^{3}$ :

$$
\rho=\frac{\rho_{w}}{1+0.01 \cdot W}
$$

In the type: $W$ - the current crushed rock humidity, $\%$.

11. We calculated the static modulus of elasticity of the crushed rock, E (MPa), by the formula:

$$
E=\frac{(1-2 \cdot \mu) \cdot P \cdot l}{(1-\mu) \cdot l_{y}}
$$

In the type: $\mu$ - Poisson ratio, taken equal to $0.30 ; P-$ the pressure on the crushed rock layer applied in the deformation measurement, MPa; $l$ - the height of the sample in the mould, $\mathrm{mm}$, defined according to the dependence: 


$$
l=H-h
$$

In the type: $H$ - the mould height, mm; $h$ - the average height from the upper edge of the mould to the crushed rock layer, мm; $l_{y}$ - the magnitude of the elastic deformation, $\mathrm{mm}$.

All the laboratory tests were carried out using the samples of crushed rocks of different particle size distribution shown in Table I.

TABLE I. Selected size distributions of crushed rocks

\begin{tabular}{|c|c|c|c|c|c|c|}
\hline \multirow{2}{*}{$\begin{array}{c}\text { \# of the } \\
\text { mixture }\end{array}$} & \multicolumn{7}{|c|}{ Total residue, \%, on sieve of size, mm: } \\
\cline { 2 - 7 } & $\mathbf{1 0}$ & $\mathbf{5}$ & $\mathbf{2 . 5}$ & $\mathbf{0 . 6 3}$ & $\mathbf{0 . 1 6}$ & $\mathbf{0 . 0 5}$ \\
\hline \# 1 & 9.70 & 24.09 & 33.08 & 48.91 & 56.64 & 71.83 \\
\hline \# & 12.93 & 28.91 & 46.90 & 55.70 & 66.86 & 77.47 \\
\hline$\# 3$ & 33.95 & 48.33 & 61.82 & 61.82 & 81.14 & 85.48 \\
\hline$\# 4$ & 48.50 & 58.09 & 62.58 & 66.54 & 69.63 & 80.92 \\
\hline$\# 5$ & 29.10 & 43.48 & 61.47 & 69.39 & 77.11 & 83.63 \\
\hline$\# 6$ & 19.40 & 38.58 & 52.07 & 67.90 & 79.49 & 83.83 \\
\hline$\# 7$ & 38.80 & 57.98 & 66.97 & 66.97 & 86.29 & 88.46 \\
\hline$\# 8$ & 58.19 & 72.58 & 81.57 & 89.49 & 93.35 & 93.35 \\
\hline$\# 9$ & 48.50 & 58.09 & 67.08 & 75.00 & 78.86 & 85.37 \\
\hline$\# 10$ & 58.19 & 67.79 & 76.78 & 80.74 & 83.06 & 88.26 \\
\hline
\end{tabular}

The proposed theoretical model was implemented by computer simulation method. The results of the simulation are presented in Table II.

TABLE II. The optimum particle size distribution of the crushed rock as a result of theoretical research

\begin{tabular}{|c|c|c|c|c|c|c|c|c|c|c|c|c|c|c|}
\hline $\begin{array}{l}\text { Component } \\
\text { diameter, } \\
\text { MM }\end{array}$ & 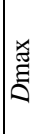 & 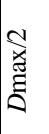 & 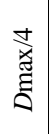 & 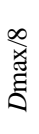 & 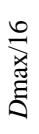 & 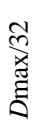 & 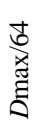 & 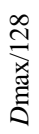 & 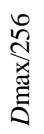 & 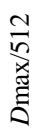 & 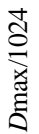 & 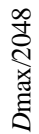 & 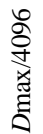 & 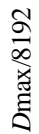 \\
\hline $\begin{array}{l}\text { Total } \\
\text { volume } \\
\text { content of } \\
\text { the } \\
\text { components } \\
\text { (total } \\
\text { residue), \% }\end{array}$ & $\stackrel{\vec{i}}{\text { in }}$ & $\begin{array}{l}n \\
\infty \\
\infty \\
n\end{array}$ & $\begin{array}{l}\infty \\
0 \\
\dot{0}\end{array}$ & 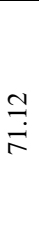 & 命 & $\stackrel{F}{尺}$ & $\begin{array}{l}\text { రి } \\
\stackrel{\infty}{0}\end{array}$ & 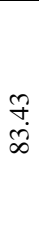 & $\frac{\bullet}{\mathscr{\infty}}$ & $\begin{array}{l}\infty \\
\infty \\
\infty\end{array}$ & $\begin{array}{l}\bar{b} \\
\infty \\
\infty\end{array}$ & $\frac{3}{\sigma}$ & $\begin{array}{l}\bar{\sigma} \\
\text { ๙ે }\end{array}$ & $\begin{array}{l}\hat{0} \\
\text { ma }\end{array}$ \\
\hline
\end{tabular}

The results obtained allowed the theoretical dependence to be determined characterizing the optimal particle size distribution of the crushed rock:

$$
V_{D}=52.4+\int_{D}^{0.5 D \max }\left(\frac{\frac{30}{(D \max +25)^{0.5}}+1.84}{D^{0.8}}\right) d D
$$

In the type: $V_{D}$ - the summed volume content of icomponent and all the previous larger components, $\% ; D$ - the average diameter of $i$-component particles, $\operatorname{mm} ; D \max -$ the average diameter of the largest component particles, $\mathrm{mm}$.
The results of laboratory tests are shown in Figures 1 and 2 in relation to the crushed coarse-grained sandstone rocks with a maximum grain size $D \max =20 \mathrm{~mm}$.

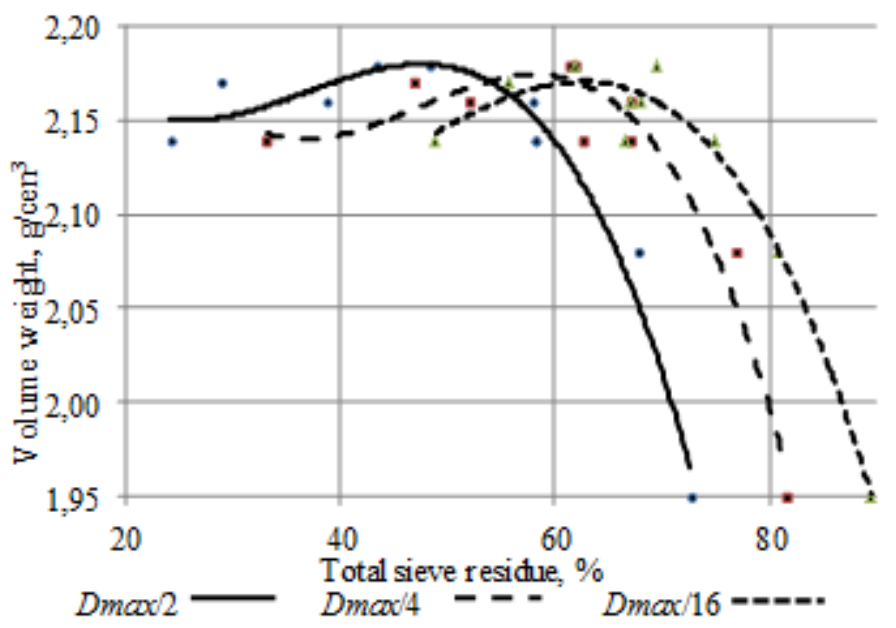

Fig.1. Dependence of the bulk density on the total residue on the sieve of a given size

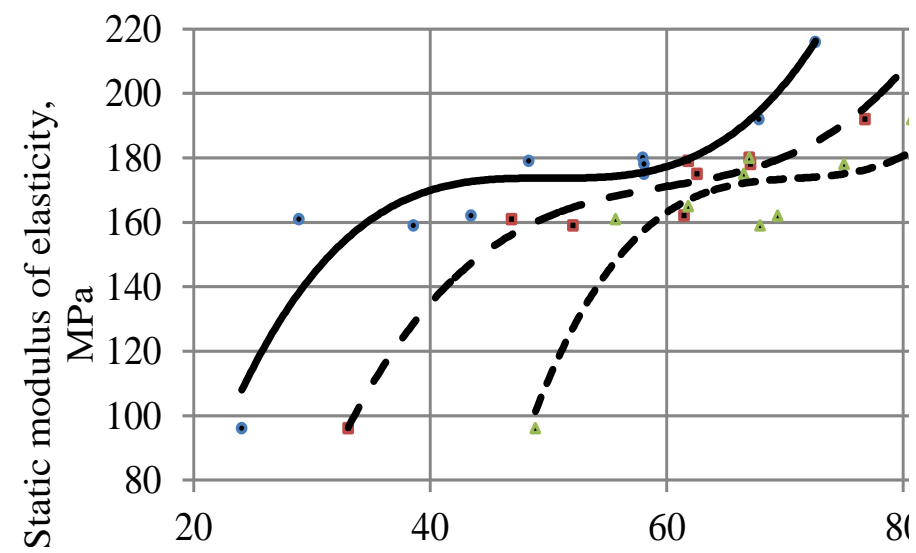

Fig.2. Dependence of static modulus of elasticity on the total residue on the sieve of a given size

The response bulk density function $(\rho)$ and the static modulus of elasticity (E) of the crushed rocks from the total residue on the sieve of a given size are the following (the values of the Beta coefficients are shown in Table III):

$$
\begin{gathered}
\rho\left(V_{D}\right)=0,79 \cdot \rho_{0} \cdot\left[\cos \left(\frac{V_{D}^{2}-k_{1}}{k_{2}}\right)\right]^{2} \\
E\left(V_{D}\right)=\int_{0}^{V_{D}} k_{3} \cdot V_{D}^{k_{4}} \cdot\left[1-\cos \left(k_{5} \cdot V_{D}\right)\right]^{k_{6}} d V_{D}+40
\end{gathered}
$$

In the type: $V_{D}$ - the share of the particles of size not more than $D \mathrm{~mm}$ in the crushed rock, $\% ; \rho_{0}-$ the input rock density, $\mathrm{g} / \mathrm{cm}^{3} ; k_{1}, k_{2}, k_{3}, k_{4}, k_{5}, k_{6}$ - the beta coefficients. 
TABLE III. Beta coefficients

\begin{tabular}{|c|c|c|c|c|c|c|}
\hline \multirow{2}{*}{$\begin{array}{c}\text { Average } \\
\text { diameter }\end{array}$} & \multicolumn{7}{|c|}{ Beta coefficient magnitude } \\
\hline$D$ max/2 & 800 & 9000 & 13.5 & -0.537 & 0.091 & 0.721 \\
\hline$D \max / 4$ & 1800 & 10000 & 0.838 & 0.223 & 0.075 & 0.822 \\
\hline$D \max / 8$ & 2800 & 13000 & 0.032 & 1.06 & 0.070 & 0.700 \\
\hline$D \max / 16$ & 3200 & 14000 & 0.0028 & 1.60 & 0.060 & 0.600 \\
\hline
\end{tabular}

The developed method of estimation of the strength characteristics (ultimate shear strength) for coarse soils, which are not much different from the crushed rocks, are presented in the source [19]. It is based on dependence of the internal friction angle and the specific crushed rock cohesion on the particle content (debris) having a size of more than $2 \mathrm{~mm}$. Then the ultimate shear resistance calculation is carried out according to Coulomb's law. A graphical representation of the calculation results is shown in Figure 3.

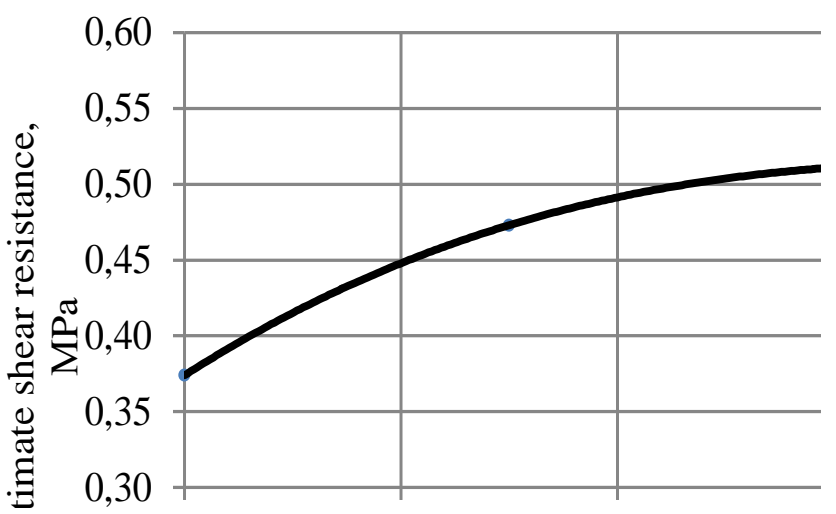

Fig.3. Dependence of the ultimate resistance crushed rock shear on the share of particles having a size of more than 2 $\mathrm{mm}$

The resulting dependences of bulk density, static modulus of elasticity and ultimate crushed rock shear strength on their particle size distribution allow performing its optimization. All three characteristics are taken as the optimization parameters.

Since according to the experimental design theory [20] the optimization parameter should be one, in order to perform the three criteria optimization, it was decided to use not the absolute values of the optimization parameters, and their relative values, defined by relationships:

$$
K_{\rho}=\frac{\rho_{i}}{\rho_{\max }}, K_{E}=\frac{E_{i}}{E_{\max }}, K_{\tau}=\frac{\tau_{i}}{\tau_{\max }}
$$

In the type: $\rho_{i}, E_{i}, \tau_{i}-I$ values of respectively bulk density, static modulus of elasticity and the ultimate crushed rock shear strength of the specified particle size distribution; $\rho_{\max }, E_{\max }, \tau_{\max }-$ the maximum values of respectively bulk density, static modulus of elasticity and the ultimate crushed rock shear strength observed in their research and analysis.

This made it possible to transform the three optimization parameters in the determined sum:

$$
K_{\Sigma}=K_{\rho}+K_{E}+K_{\tau}
$$

To find the optimal size distribution the dependences of $K_{\rho}, K_{E}, K_{\tau}$ и $K_{\sum}$ on the share of the particles of size larger than the predetermined one in the composition of crushed rock were determined (Figures 4, 5). In Figure 5, a line with an arrow also shows the theoretically optimum content of particles with a defined particle size obtained by the results of theoretical research.

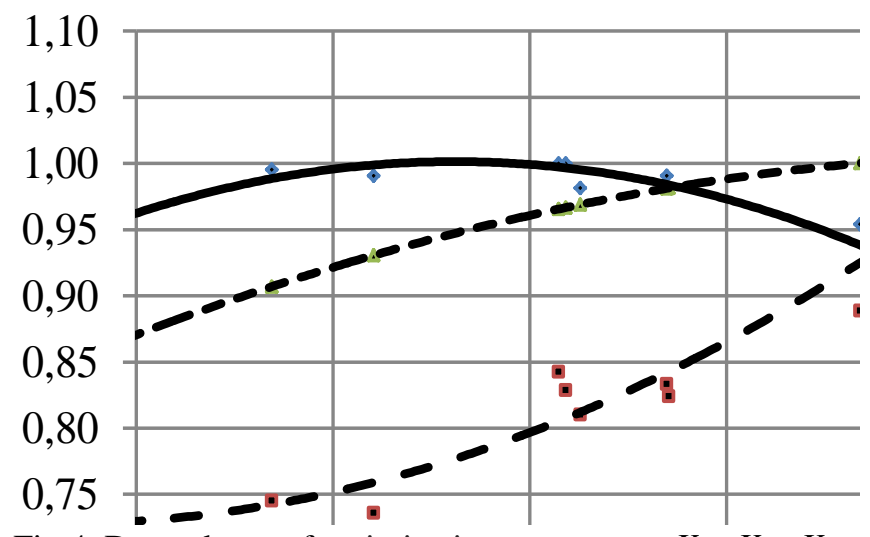

Fig.4. Dependence of optimization parameters $K_{\rho}, K_{E}, K_{\tau}$ on the total residue on the $2.5 \mathrm{~mm}$ sieve

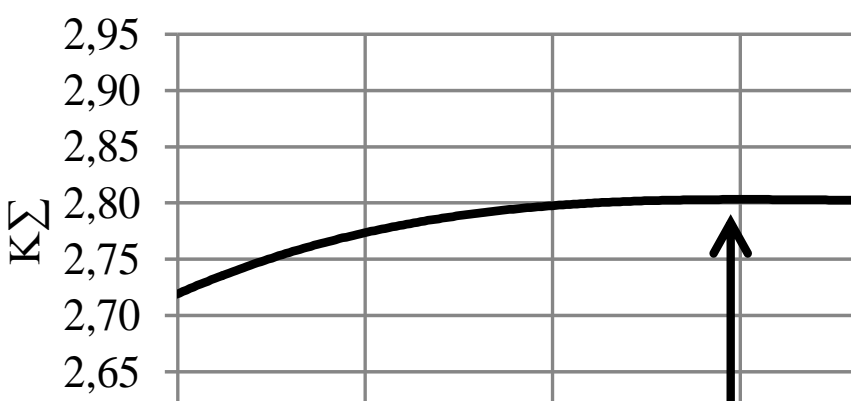

Fig.5. Dependence of optimization parameters $K_{\Sigma}$ on the total residue on the $2.5 \mathrm{~mm}$ sieve

The comparison of empirical data (Figure 5) with the results of theoretical studies shows that they are almost identical. The difference is that according to the results of experimental data, the optimal size distribution constitutes an area, and for theoretical studies - a single value in this optimum region. Consequently, the dependence that characterizes the optimal particle size distribution of crushed rock, can be written as:

$$
V_{D}=(40 \ldots .55)+\int_{D}^{0.5 D \max }\left(\frac{\frac{30}{(D \max +25)^{0.5}}+1.84}{D^{0.8}}\right) d D
$$

Other physical and mechanical characteristics, the main of which are crushability, abrasion, water resistance and frost resistance should be taken into account, in addition to particle size distribution, to the crushed rock to ensure the efficiency of openpit road pavement within the specified service life [21].

Cylinder crushing value is the main strength characteristic of the crushed rock that characterizes the intensity of the grain refinement during the open-pit road operation. According to 
the public road service experience the normative document [9] defines the minimum acceptable rock crushability grades, which are not less than the M600 for the toppings and M400 for the bases. Since the methodologies for determining the ultimate uniaxial compression strength and propagation velocity of elastic longitudinal and transverse waves [22-24] are applicable to rock massifs rather than the crushed rocks, their application for evaluation of crushability grade is not correct. Therefore, we need a method to quickly and reliably determine the suitability of the rock for the open-pit pavement layers.

One of the methods meeting the conditions imposed, is the method of measuring the time and the propagation velocity of the ultrasonic pulse from the transmitter to the receiver. For its practical application it is necessary to know the relationship between the ultimate rock compression strength in the watersaturated state and the propagation rate of longitudinal ultrasonic waves in it.

Panachev I.A., Ryzhkov Y.A., Shalamanov V.A., Stumpf G.G. conducted numerous studies of physical and technical characteristics of the rocks and coals of Kuznetsk coal basin $[25,26]$, the statistical and mathematical processing of which allowed to establish the relationship between the rock crushability value in the water-saturated state and the of propagation velocity of longitudinal ultrasonic waves in the water-saturated rocks (Figure 6):

$$
M=9.81 \cdot\left(a+b \cdot V_{\text {prograp }}+c \cdot V_{\text {prograp }}^{2}\right)
$$

In the type: $M-$ the rock crushability value in the watersaturated state; $a, b, c$-non-dimensional coefficients of response function, depending on the rock type (Table IV); $V_{\text {prograp }}-$ propagation speed of longitudinal ultrasonic wave, $\mathrm{m} / \mathrm{s}$.

Table IV. Non-dimensional coefficients of response function

\begin{tabular}{|c|c|c|c|}
\hline Brief description of the rock & $\boldsymbol{a}$ & $\boldsymbol{b}$ & $\boldsymbol{c}$ \\
\hline medium granular sandstone & 48.08 & -0.0376 & 0.00000987 \\
\hline coarsely granular sandstone & -13.71 & 0.00214 & 0.0000052 \\
\hline fine granular siltites & 106.81 & -0.072 & 0.000015 \\
\hline
\end{tabular}

The analysis of the relationships shows that the coarsely granular sandstone can be used for the road bases without any restrictions, and for the toppings - with the propagation velocity of longitudinal ultrasonic waves of more than 3600 $\mathrm{m} / \mathrm{s}$. The medium granular sandstone and the fine-grained siltstone are practically not suitable for the toppings and can only be used for road bases at the propagation speed of longitudinal ultrasonic-waves of more than $3500 \mathrm{~m} / \mathrm{s}$.

The abrasion value is the additional characteristic of crushed rocks, characterizing their amortization (abrasion) under the loads of open-pit motor transport. The importance of this indicator is determined by the decrease of the bearing capacity of the structural layer with increasing share of fine dust particles (Figures 2, 3), and the increase in dusty air of the working area. The normative reference [9] establishes the requirements for the minimum abrasion grade of crushed rocks, which is not less than A 3 for the toppings and A4 for the bases.

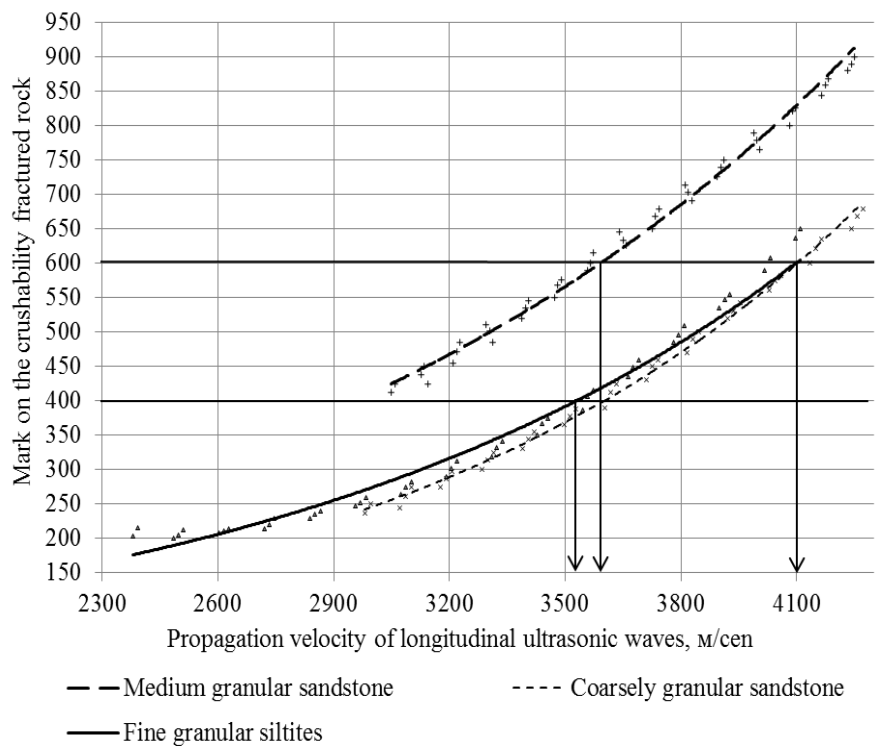

Fig.6. Graph of dependency of rock crushability grade in the water-saturated state on propagation velocity of longitudinal ultrasonic wave

One of the standardized physical characteristics is the frost resistance grade, which characterizes the number of cycles of alternate freezing and thawing, which the crushed rock mass can withstand at no more than $5(10) \%$ mass loss. The importance of this indicator is determined by the need to limit the formation of rock stuff over the pavement life, affecting, as noted above, the reduction of the bearing capacity of the structural layer.

The requirements for this indicator should be determined primarily on the basis of the analysis of climatic conditions of the construction area. Thus, according to statistical observations of weather stations in the Kemerovo region [27] it was established the cumulative number of cycles of alternate freezing and thawing of the upper layers of soil to a depth of $10 \mathrm{~cm}$ during 16 years of observation (Figure 7), which revealed the dependence of the desired crushed rock frost resistance value on the service life of the open-pit roads:

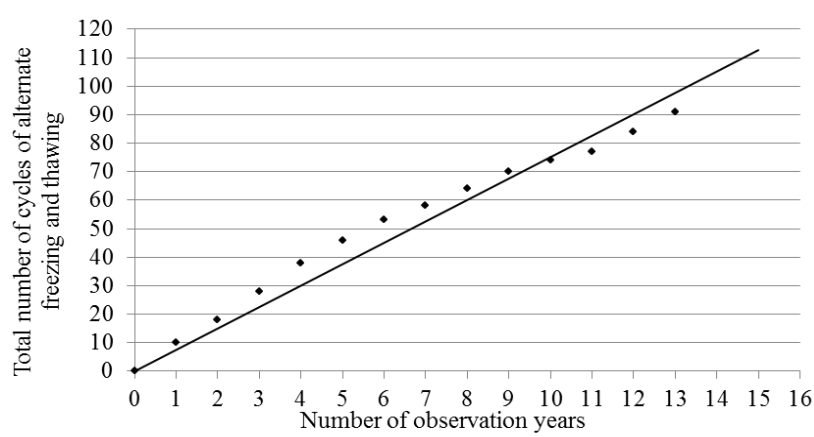

Fig.7. Graph of dependency of the aggregate number of cycles of alternate freezing and thawing on the number of observation years 


$$
F_{\text {req }}=f_{\text {year }} \cdot T_{\text {empl }}
$$

In the type: $F_{r e q}$ - the required frost resistance value; $f_{\text {year }}$ - coefficient of linear regression equation, numerically equal to the average arithmetic of cycles of alternate freezing and thawing of the toppings over the year, obtained as a result of observations for 10-15 years (for the Kemerovo region $f_{\text {year }}=7$ ); $T_{\text {empl }}$ - technological road service life, years.

The resulting dependence allows to assign reasonably the required frost resistance grades of crushed rock used for openpit road pavement layer (Table V).

Table V. The required frost resistance grades depending on the service life of the road in the climatic conditions of Kemerovo region

\begin{tabular}{|c|c|}
\hline $\begin{array}{c}\text { The target road service life, } \\
\text { years }\end{array}$ & The required frost resistance grades \\
\hline till 2 & F15 \\
\hline from 2 to 3 & F25 \\
\hline from 3 to 7 & F50 \\
\hline More than 7 & F100 \\
\hline
\end{tabular}

Another important indicator is the required water resistance grade characterizing the crushed rock weight loss under the influence of water [28]. This figure, as well as the frost resistance grade, limits the possible stone chipping, reducing the bearing capacity of the structural pavement layers. According to the experience of public roads service, the required water resistance grades are regulated [9], which should be no lower than B1 for crushed rock used for the topping, and B2 - for the road base.

\section{CONCLUSION}

1. The optimum particle size distribution of the crushed rock, providing simultaneously the high bulk density values, the static modulus of elasticity and the ultimate shear strength is reached when the share of particles larger than half of the maximum amounts from 40 to $55 \%$ and integrally increases with the average particle diameter decrease.

2. The crushability grade of crushed rock in watersaturated state increases nonlinearly with the increasing propagation velocity of longitudinal ultrasonic waves. The coarse-grained sandstone can be used for the construction of open-pit automobile road base without restrictions, and for the topping - with propagation velocity of longitudinal ultrasonic waves of at least $3600 \mathrm{~m} / \mathrm{s}$. The medium-grained sands and fine-grained siltstone can be used for the construction of the technological road base, if the propagation velocity of longitudinal ultrasonic waves is not less than $3500 \mathrm{~m} / \mathrm{s}$.

3 . The required frost resistance grade of crushed rock increases linearly with the increasing service life of technological roads and makes in Kuzbass conditions F15 for the service life of up to 2 years old, F 25 - from 2 to 3 years, F50 - from 3 to 7 years and F100 - more than 7 years.

\section{REFERENCES}

[1] Afinogenov O.P., Shalamanov V.A., Shabaev S.N., Afinogenov A.O.Karernye avtomobil'nye dorogi: sovershenstvovanie metodov proektirovanija zemljanogo polotna i dorozhnyh odezhd [Career roads: improvement of methods for design of subgrade and pavement]. O.P. Afinogenov, Kemerovo, Ofset, 2015. 222 P.

[2] Bujanikn, A.V. Kompleksnaja ocenka i prognozirovanie pokazatelej kachestva jekspluatacii karernyh avtosamosvalov [Comprehensive assessment and forecasting of indicators of quality of operation of openpit dump truck]. Kemerovo, Kuzbass State Technical University, 2004. $305 \mathrm{P}$.

[3] Shalamanov V.A, Shabaev S.N, Krupina N.V. Ocenka jekonomicheskoj jeffektivnosti pri provedenii meroprijatij po uluchsheniju kachestva pokrytij karernyh avtomobil'nyh dorog [Evaluation of economic efficiency of interventions to improve the quality of coatings career automotive roads]. Vestnik Kuzbasskogo Gosudarstvennogo Tehnicheskogo Universiteta [Bulletin of Kuzbass State Technical University]. 2007. No. 3. P. 54-55.

[3] Vasilev, M.V. Transportnye processy i oborudovanie na karerah [Transport processes and equipment for quarries]. Moscow, Nedra, 1986. $240 \mathrm{P}$.

[4] Rukovodstvo po proektirovaniju i stroitelstvu vremennyh tehnologicheskih avtodorog na razrezah Proizvodstvennogo Obedinenija "Kemerovougol" [Guide for the design and construction of temporary technological roads at open-pit mines of the Production Association "Kemerovo coal"]. Kemerovo, Kuznetsky branch of the Scientific-research and design Institute of mining of minerals by open method of the Ministry of coal industry of the USSR, 1988. 85 P.

[5] Smirnov V.P, Torov V.S. Stroitelstvo i jekspluatacija tehnologicheskih avtodorog na Mihajlovskom gorno-obogatitelnom kombinate [Construction and operation of technological roads at Mikhailovsky GOK]. Gornyj zhurnal [Mining journal]. 1989. No. 9. P. 23-25.

[6] Krasnoshtanov R.F, Zyrjanov I.V. Tehnologicheskij transport na karerah [Technological transport in quarries]. Gornyj zhurnal [Mining journal]. 1994. No. 9. P. 30-33.

[7] Eremeev V.I, Zabelin V.V, Shurygin V.V. Skorost dvizhenija avtosamosvalov po karernym dorogam [The speed of movement of career dump trucks on the roads]. Gornyj zhurnal [Mining journal]. 1995. No. 4. P. 51-52.

[8] SP 34.13330.2012. Avtomobilnye dorogi. Aktualizirovannaja redakcija SNiP 2.05.02-85* [Set of rules 34.13330.2012. Highways. The updated edition of the Building Regulations 2.05.02-85*]. Ministerstvo regionalnogo razvitija Rossijskoj Federacii [Ministry of Regional Development of the Russian Federation]. Moscow, 2012. 106 P.

[9] SP 37.13330.2012. Promyshlennyj transport. Aktualizirovannaja redakcija SNiP 2.05.07-91* [Set of rules 37.13330.2012. Industrial vehicles. The updated edition of the Building Regulations 2.05.02-85*] Ministerstvo regionalnogo razvitija Rossijskoj Federacii [Ministry of Regional Development of the Russian Federation]. Moscow, 2012. 152 P.

[10] Instrukcija po raschetu dorozhnyh odezhd nezhestkogo tipa dlja karernyh dorog pod avtosamosvaly gruzopodemnostju 27-180 t [Instructions on the calculation of non-rigid pavements such as roads for mining dump trucks with carrying capacity for 27-180 tons]. Gosstroj SSSR. Glavnoe upravlenie proektirovanija PROMTRANSNIIPROEKT [USSR State Building. The main design management "Design and Research and Research Institute of Industrial Transport"]. Moscow, 1988. 60 P.

[11] Jumashev V.M, Turenk K. Primenenie maloprochnyh kamennyh materialov [The use of low-strength stone materials]. Avtomobilnye dorogi [Highways]. 1990. No. 7. P. 17-18.

[12] Dobrov E.M. Krupnooblomochnye grunty v dorozhnom stroitelstve [The coarse-grained soils in road construction]. Moscow, Transport, 1981. 180 P.

[13] Ivanov N.N. Stroitelstvo avtomobilnyh dorog; ch. 1. [The construction of roads; part. 1]. Moscow, Auto transport, 1963. $516 \mathrm{P}$.

[14] L. M. Le Pen, W. Powrie, A. Zervos, S. Ahmed, S. Aingaran. Dependence of shape on particle size for a crushed rock railway ballast.Granular Mater. 2013. Vol. 15, No. 6. P. 849-861.

[15] Birjukov A.V. Usrednenie i smeshivanie dispersnyh sistem [Averaging and blending of disperse systems]. Vestnik Kuzbasskogo Gosudarstvennogo Tehnicheskogo Universiteta [Bulletin of Kuzbass State Technical University]. 2000. No. 7. P. 17-18. 
[16] Radovskij B.S. Plotnost besporjadochnoj upakovki tverdyh chastic sfericheskoj formy [Random packing density of the solid particles of spherical shape]. Izvestija Akademii nauk SSSR. Mehanika tverdogo tela [Proceedings of the USSR Academy of Sciences. Mechanics of Solids]. 1972. No. 4. P. 193- 198.

[17] Kandaurov I.I. Mehanika zernistyh sred i ee primenenie v stroitelstve [The mechanics of granular environments and its use in construction]. Leningrad branch of Construction Publishing, 1988. $281 \mathrm{P}$.

[18] Metodika ocenki prochnosti i szhimaemosti krupnooblomochnyh gruntov s pylevatym i glinistym zapolnitelem i pylevatyh i glinistyh gruntov s krupnooblomochnymi vkljuchenijami [Methods of assessing the strength and compressibility of coarse soils with silt and clay filler and silt and clay soils with coarse inclusions]. DalNIIS [Far Eastern Research, Design and Technology Institute for Construction]. Mocsow, 1989. 24 P.

[19] Ljubchenko E.A., Chudnova O.A. Planirovanie i organizacija jeksperimenta: uchebnoe posobie. Chast 1 [Planning and organization of the experiment: a tutorial. Part 1]. Vladivostok, Publisher Pacific State Economic University, 2010. 281 P.

[20] Shalamanov V.A, Boyko D.V. Ocenka vozmozhnosti ispolzovanija uglevmeshhajushhih gornyh porod Kuzbassa dlja ustrojstva tehnologicheskih dorog [Evaluation of the possibility of using the surrounding rocks Kuzbass coal for technological devices roads]. Vestnik Kuzbasskogo Gosudarstvennogo Tehnicheskogo Universiteta [Bulletin of Kuzbass State Technical University]. 2013. No. 3. P. 55-57.

[21] GOST 21153.2 - 84*. Porody gornye. Metody opredelenija predela prochnosti pri odnoosnom szhatii [State Standard 21153.2 - 84 *. Rocks. Methods for determining the tensile strength under uniaxial compression]. Izdatelstvo standartov [standards Publishing House]. Moscow, 1984. 8 P.
[22] GOST 21153.7-75*. Porody gornye. Metod opredelenija skorostej rasprostranenija uprugih prodolnyh i poperechnyh voln [State Standard 21153.7-75*. Rocks. A method of determining the velocity of propagation of elastic longitudinal and transverse waves]. Izdatelstvo standartov [standards Publishing House]. Moscow, 1974. 7 P.

[23] GOST 31436-2011. Porody gornye skal'nye dlja proizvodstva shhebnja dlja stroitelnyh rabot. Tehnicheskie trebovanija i metody ispytanij [State Standard 31436-2011. Rocks rock for production of crushed stone for construction works. Technical requirements and test methods]. Izdatelstvo standartov [standards Publishing House]. Moscow, 2011. 157 P.

[24] Shtumpf G.G. Fiziko-tehnicheskie svojstva gornyh porod i uglej Kuzneckogo bassejna [Physico-technical properties of rocks and coal of the Kuznetsk basin]. Moscow, Nedra, 1994. 447 P.

[25] Panachev I.A, Shalamanov V.A, Shtumpf G.G, Ryzhkov Ju.A. Osobennosti otkrytoj dobychi i pererabotki uglej slozhnostrukturnyh mestorozhdenij Kuzbassa [Features of open-pit mining and coa processing complex fields of Kuzbass]. Kemerovo, Kuzbass University publishing house, 1997. 220 P.

[26] The climate guide cities of Russia [Klimaticheskij spravochnik gorodov Rossii]. URL: http://www.atlasyakutia.ru/weather/spravochnik/temp_grunt/climate_sprav-temp_grunt 2964201307.php

[27] D. Ma, X. X. Miao, G. H. Jiang, H. B. Bai, Z. Q. Chen. An Experimental Investigation of Permeability Measurement of Water Flow in Crushed Rocks // Transport in Porous Media. 2014. Vol. 105, No. 3. P. 571-595. 